\title{
Capital market penalties to radical and incremental innovation
}

\section{Daniel Stefan Hain and Jesper Lindgaard Christensen Department of Business and Management, Aalborg University, Copenhagen, Denmark}

\begin{abstract}
Purpose - The purpose of this paper is to investigate how access to financing for incremental as well as radical innovation activities is affected by firm-specific structural and behavioral characteristics.

Design/methodology/approach - Deploying a two-stage Heckman probit model on survey data spanning the period 2000-2013 and covering 1,169 firms, this paper analyzes the effect of a firm's engagement in incremental and radical innovation on its likelihood to get constrained in their access to external finance, and how this effect is moderated by the firm's age and size.

Findings - In line with earlier research, it is confirmed that the type of innovation matters for the access to external finance, but in a more nuanced way than generally portrayed. While incremental innovation activities have little negative effect on the access to external finance, radical innovation activities tend to be penalized by capital markets. This effect appears to be particularly strong for small firms.

Originality/value - This paper provides nuanced insights into the interplay between types of firm-level innovation activities, structural characteristic and access to external finance.
\end{abstract}

Keywords Radical innovation, Asymmetric information, Financial constraints, Financing innovation

Paper type Research paper

\section{Introduction}

Access to external financing represents a critical factor in determining firms' ability to survive, grow and engage in innovative activities (Beck and Demirguc-Kunt, 2006; Brancati, 2015; Mina et al., 2013; Musso and Schiavo, 2008). In turn, innovation is argued to be associated with competitive advantage (Chatzoglou and Chatzoudes, 2018). Innovation financing is therefore crucial to firms' development. Large parts of this debate including our contribution have centered around external financing of innovation, yet similar arguments apply to the allocation of firm internal funding (Das et al., 2018). Some characteristics of firms make them less likely to raise the necessary external capital to fund innovation projects. In particular, firms who are young, small and engaged in innovation projects are said to be subject to information asymmetries between them and their potential financiers, hence, less likely to raise the necessary external capital to fund innovation projects (Carpenter and Petersen, 2002; Carreira and Silva, 2010; Freel, 2007; Hall, 2010; Lee et al., 2015). In addition to structural characteristics of firms, also a firm's behavior matter for financiers. Hence, we pose the following overall research question:

$R Q 1$. What is the relative importance of structural and behavioral factors in explaining financial constraints, and how do they interact?

In this paper, we contribute to the existing literature in the field in several manners. First and foremost, we investigate how access to external financing for innovation activities is

JEL Classification - O31, G23, G24, L25

(C) Daniel Stefan Hain and Jesper Lindgaard Christensen. Published by Emerald Publishing Limited. This article is published under the Creative Commons Attribution (CC BY 4.0) licence. Anyone may reproduce, distribute, translate and create derivative works of this article (for both commercial and non-commercial purposes), subject to full attribution to the original publication and authors. The full terms of this licence may be seen at http://creativecommons.org/licences/by/4.0/legalcode
Radical and incremental innovation

Received 9 July 2018 Revised 2 November 2018 26 December 2018 Accepted 28 December 2018 . 
EJIM

23,2

292

affected by multiple types of firm-specific structural and behavioral characteristics. Here, we operationalize variables describing firms in their objective dimensions such as size, age, location and ownership as structural characteristics. Behavioral characteristics in turn are related to firms' revealed quantity and quality of innovation activities. We propose an interaction between these characteristics, and consequently argue that not a single but rather certain combinations of structural and behavioral characteristics make firms less likely to meet their financial needs. Second, a large proportion of firms do not demand external finance, some because they do not need it (Nightingale and Coad, 2014), some because they might need it but do a self-assessment of their likelihood to obtain finance that discourage them from entering the loan market (Kon and Storey, 2003). A number of earlier surveys of financial constraints, some of which has inspired policy making in the field, has not taken demand and possible endogeneity problems into account rendering a possible biased estimation of both the extent and nature of the problem (Carreira and Silva, 2010; D'Este et al., 2012). Third, using a two-stage Heckman probit model accounting for the heterogeneous need for external finance, we analyze the impact of firms' structural and behavioral characteristics on access to external capital. We use a unique firm-level data set composed of longitudinal survey data coupled with performance indicators, allowing us to incorporate micro-level firm characteristics. The data comprise a yearly survey of innovation activities and financial constraints that covers 14 years, from 2000 through 2013, with information on both demand and supply of external financing. Compared to traditional innovation surveys (such as the Community Innovation Survey (CIS)), the data include more frequent rounds of surveying and a more detailed set of questions on finance. A contribution of this study is therefore to provide a more fine-grained picture of financial constraints. Finally, most previous studies used dichotomous innovation indicators (e.g. Lee et al., 2015; Pellegrino and Savona, 2017), whereas we use a continuous innovation intensity measure that is arguably better suited to investigate the question "how much innovation is a good thing" (Freel, 2007; Freel et al., 2012).

We find evidence that the effect of innovation on capital demand and supply is not uniform, but rather interdependent with firm characteristics and behavior. Specifically, we find that the type of innovation matters, on its own right as well as a moderating factor. While incremental innovation activities have little effect on the access to external finance, radical innovation activities tend to be penalized by capital markets. This appears to be particularly true for small innovators. We link these findings to how capital markets assess information flows. We also relate the findings to the design and eligibility criteria of policy schemes to spur innovation finance and to what implications are for innovation managers.

The remainder of the paper is structured as follows. In Section 2, we first survey the existing literature with respect to earlier studies of financial constraints, and derive a set of testable hypotheses on the interplay of innovation intensity, firm characteristics and contextual factors. The empirical strategy, data and variables are presented and explained in Section 3. Section 4 reports the results, followed by a discussion in Section 5, followed by the concluding Section 6 .

\section{Financial constraints - theory and hypotheses}

\subsection{Asymmetric information and financial constraints}

Asymmetric information has been recognized as a generic source of market failure in buyer-seller commodity markets (Akerlof, 1970) as well investor-investee capital markets (Myers and Majluf, 1984). Financial constraints can stem from asymmetric and imperfect information, leading to a high perceived uncertainty and the need for banks and other financiers to engage in costly gathering of firm-specific soft and private information for a proper assessment of creditworthiness (Berger et al., 2001; Carpenter and Petersen, 2002; 
Hall, 2010; Stiglitz and Weiss, 1981)[1]. Because of the difficulties associated with such assessments, financiers employ different strategies in their screening procedures, including repeated contracts and relationship banking, specialization, monitoring and independent auditing and screening, milestone financing and collateral. However, not only are these measures costly to the financier, they are also insufficient to reveal all relevant information or compensate for what remains unknown. Even collateral may in the case of innovation be problematic as the assets in innovation projects are often intangible, involves sunk costs due to high specificity, and are closely linked to human capital (Hall, 2010). Financiers are therefore particularly skeptical at the outset of the financing process when assessing proposals from firms that either have characteristics that amplify information asymmetry, innovation, smallness, newness or are historically associated with high default risk.

Moreover, literature on risk, uncertainty and investments, inform us that the investment decision-making processes cannot be fully understood as an objective optimization process pursued by fully rational agents. This is due to that capital markets entail information inefficiencies and frictions consequently the information needed to fully assess an investment's outcome is rarely complete (Jaffee and Russell, 1976), and asymmetrically distributed among market participants. Because of the incomplete information and complexity of foreseeing the outcome of investments investors make decisions under "bounded rationality" (Simon, 1955). Decision making is also guided by cognitive biases (McFadden, 2001) rooted in the investors' beliefs, experiences and social influences. When investment decisions are characterized by high complexity and uncertainty, simple heuristics become increasingly important, in the present context objective characteristics of firms can gain increased attention in the decision-making process.

\subsection{Financing innovation}

Investments in innovation embody characteristics making them substantially different from other investments in several respects (Hall, 2010). From a financier perspective, investing in firms engaged in innovation activities is foremost associated with higher information asymmetries between firm and financier, and related with higher risk and uncertainty of investment outcomes (Dosi and Orsenigo, 1988). Due to these informational deficiencies, their often weaker balance sheets and frequent lack of fixed assets that could act as collateral, and generally higher technological, market and financial risk, innovative firms are said to have a greater need to communicate their merits to financiers (Brancati, 2015; Häussler et al., 2014).

2.2.1 Innovation intensity hindering access to external finance?. The proposition that innovative firms are somewhat more likely to face financial constraints is supported by a growing body of empirical evidence. Freel (2007) argues for a nuanced understanding of innovation and financial constraints, finding that even though a little innovation seems to be positively impacting financial constraints, more intensively innovating and small firms appear to be less successful in obtaining external financing. Importantly, many of these earlier studies use innovation in the form of a dichotomous variable. We see a number of problems in these approaches and argue for new ways of measuring. Using dichotomous variables miss out important quantifications of innovation. Obviously, a large firm with a hundred products in their product portfolio where one of these is innovated (perhaps only incrementally) represents a very different situation than a small, radically innovating firm with one innovated (perhaps disruptive) product out of one or two in their portfolio. Statistically, they are treated alike in innovation statistics.

2.2.2 Types of innovation - R\&D based incremental and radical. Up to now, the majority of studies have used firms in R\&D-intensive industries (Hall, 2010), patenting firms or the simple separation of firms into innovative and non-innovative categories as proxies for
Radical and incremental innovation 
EJIM

23,2

294

innovation (Lee et al., 2015; Pellegrino and Savona, 2017). For example, Hall (2010) argues that using R\&D as a proxy for innovation is justified because it makes up a major portion of innovation expenditures in firms in CIS-like surveys. However, despite the fact that R\&D expenditures are a substantial part of innovation expenditures, only a minority of innovating firms has any R\&D at all. Many of the changes in products, processes and services are incremental, new-to-firm innovation. Consequently, it is important to recognize that innovation is ubiquitous and depends often on modes of doing and using technologies rather than being based on science or R\&D (Jensen et al., 2007). It is likely that the type of innovation is important to financiers' assessments. Mina et al. (2013) report firms engaged especially in process innovation (often associated with efficiency increasing incremental innovation) to attract more capital, while innovation projects with long-payoff periods deter financiers. They further highlight the limited validity of using R\&D expenditure as sole measurement to relate firm level innovation with financial constraints. Similarly, Brancati (2015) incorporates organizational and managerial innovation in the analyses of financial constraints, hence, also broadening the innovation definition, and linking the type of innovation to financial constraints.

2.2.3 The hypothesis. These arguments lead to two hypotheses as in the present study first compensate for this caveat by using the innovation intensity of firms instead of the innovation frequency. In quantitative terms, this innovation intensity can be properly captured with the number of innovative products, processes and services introduced by the firm in a certain period. As an output measure of innovation intensity, it also captures what is easily visible to potential financiers. Second, leading to H1b, radical and incremental innovation (operationalized as respectively firms' number of innovations, which are new to the market as opposed to innovations only new to the firm) are likely to be perceived differently by financiers. Incremental innovation activities are to a higher extent foreseeable in their outcome, hence, more appealing to investors than radically novel ones, consequently both types of innovation activities should be analyzed separately:

H1a. A firm's innovation intensity increases its likelihood to experience external financial constraints.

$H 1 b$. The effect of innovation activity on the likelihood to experience external financial constraints is more pronounced for radical than for incremental innovation.

\subsection{Structural characteristics: the liability of newness and smallness}

In addition to innovation, as discussed above, the entrepreneurial finance literature consistently identifies two characteristics of firms as being associated with asymmetric information, and consequently more financial constraints: being young and/or small. This is ascribed to the liabilities of newness and smallness, asymmetric information, agency problems, and the high, fixed costs of screening and monitoring such firms when compared to the potential profit for the financing institution (Beck and Demirguc-Kunt, 2006; Canepa and Stoneman, 2008; Carreira and Silva, 2010; Fazzari et al., 1988; Murray, 1999).

Additionally, in the case of innovation-intense firms, or firms with radical innovation, investors with only a limited understanding of firms' processes, products and markets face huge difficulties in assessing the quality of their innovation processes without undertaking substantial efforts in gathering tacit information. Until this point, we assumed the financier to be in need of understanding the very essence of the firm's innovation activities. However, traditional financiers such as banks, representing the major source of external capital to firms, rely to a high degree on the available factual, or 
hard, information, such as a firm's financial history, capital structure and available collateral, when assessing creditworthiness (as opposed to the strategies, capabilities, attitudes, etc. of firms and managers). By doing so, they leave the selection of opaque innovation projects to the firm, if the firm fulfills other requirements based on hard information. In this sense, hard and soft information regarding the firm can serve as imperfect substitutes for an assessment of creditworthiness without directly taking the nature of its innovation projects into account.

Yet, in the case of small or young firms, which tend to be more opaque to financiers (Berger et al., 2001), salient hard information such as rated debt, certified financial statements, annual reports, and other forms of codified signals and track records are often not available (Uzzi, 1999; Uzzi and Lancaster, 2003). In the absence of both hard and soft information, these particular types of firms may face substantial obstacles in obtaining external financing, especially for their innovation projects, and especially for the more radical innovation projects. As a result, firms with a certain set of characteristics appear to be consistently penalized by capital markets, namely, those that are young, small and technology based (e.g. Beck and Demirguc-Kunt, 2006; Canepa and Stoneman, 2008; Canton et al., 2013; Carreira and Silva, 2010; Colombo and Grilli, 2007; Freel, 2007; Giudici and Paleari, 2000; Hall, 2010). The simultaneous presence of these features will amplify the risk that financiers face. Consequently, we expect the effects of size and age, to positively moderate the effect of innovation intensity and radical innovation on its access to external capital:

H2a. Firm age as well as size moderate the negative effect of innovation intensity on external financial constraints, making the relationship weaker for old and large firms.

$H 2 b$. The moderating effect of age and size is more pronounced for radical than incremental innovation intensity.

The operationalization of our empirical strategy and the underlying theoretical model is illustrated in Figure 1[2].

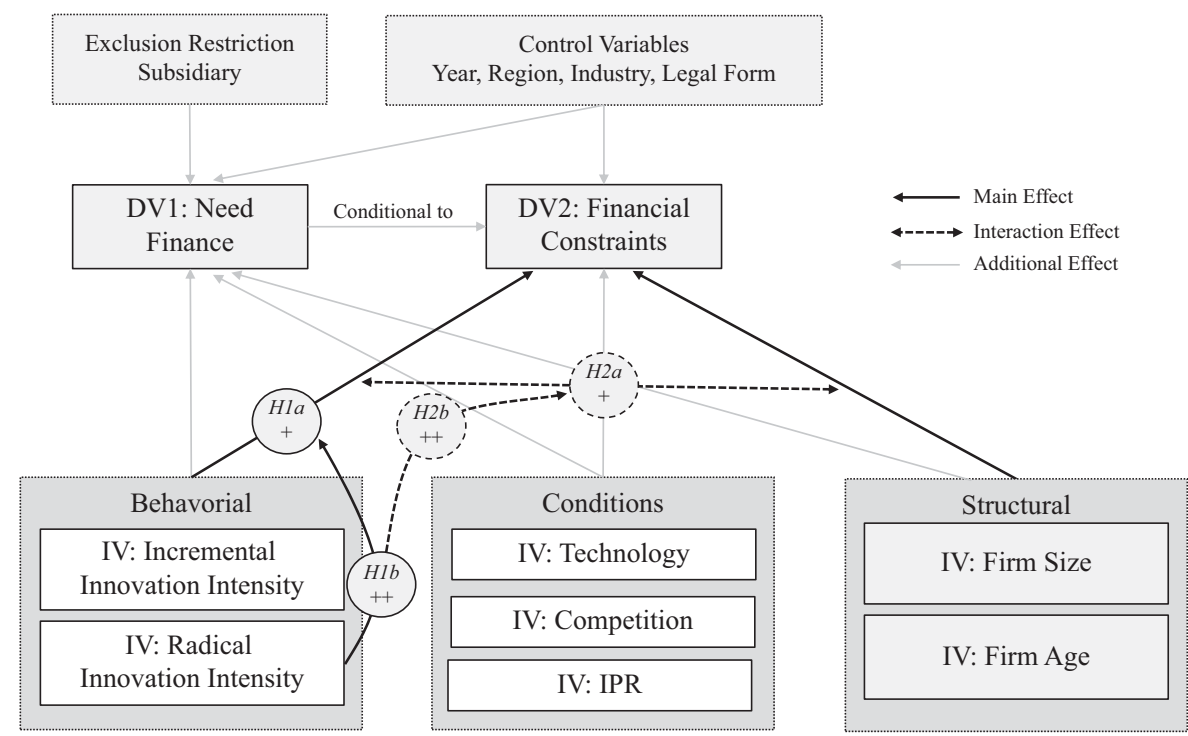

Radical and incremental innovation

295
Figure 1. Illustration of the theoretical and empirical model 
EJIM

23,2

296

\section{Data and econometric strategy}

\subsection{Data sources and context}

Our primary data come from a survey of private firms with at least five employees the in manufacturing, business services, and building and construction industry, located in Denmark's North Jutland region[3]. Initial sampling was done in a manner that ensured representativeness for the population of above-mentioned firms in the region, and the yearly surveys were adjusted to ensure that the sample continued to be representative for the population.

Respondents annually responded to questions regarding their views of the past, present and future development of variables like production, employment, profit, innovation activities and access to financial capital. Due to the innovation finance focus of the survey, we only included firms reporting that they currently engage in innovation activities or plan to do so in the future. To ensure a shared understanding, the questions on innovation were posed only to a sub-sample of the population of private sector firms, such as those in the manufacturing industry and business services. The phrasing of the questions largely followed the form in which CIS pose questions on innovation and finance (e.g. Canepa and Stoneman, 2008; Pellegrino and Savona, 2017), making the results partly comparable to studies based on CIS data. Direct comparisons with, e.g., CIS are, though, difficult because we study yearly innovation in a 10 year time period and use innovation intensity as our primary innovation variable. But as explained in Section 3.3, below 40 percent of firms in our sample introduced an innovation. Compared to CIS-figures this is broadly in line with the level of innovation frequency in Denmark[4]. Other variables in CIS and our survey results are also on par, indicating that we adequately capture innovation activities not only in the region but also in Denmark.

Our case region is located in the north of Denmark. Regional differences in Denmark are relatively small, and as Denmark has for several years been in the top-3 of the European Innovation Scoreboard (Hollanders and Es-Sadki, 2017) this is an adequate setting to study both incremental and radical innovation. There is one urban center in the region, Aalborg, and the industry structure is somewhat different within the region, with the majority of R\&Dbased firms being in the Aalborg area. We control for this difference in our analyses[5].

\subsection{Variable description}

The following subsection briefly describes the variables utilized in the empirical analysis and gives suggestions regarding their impact. A summary of all variables and their computation can be found in Table I.

Dependent variables. Since we employ a two-stage selection model, we have a main dependent variable of interest on the second stage, as well as a qualifying selection variable on the first stage. Our main dependent variable of interest (constraints) is dichotomous and derived from the survey answers whether the firm experienced constraints in raising external capital to finance innovation projects in the corresponding period (0: No, 1: Yes). Hence, following a number of earlier studies of financial constraints such as Brancati (2015), Mohnen et al. (2008), Savignac (2008), and Silva and Carreira (2012), our key variables are self-reported. The question is first asked broadly on any type of capital to finance innovation, which is the question we use. In an additional survey question it is asked whether debt or equity is the primary constraint. While it ideally would be nice to know about the objectives and scale of financing needs as well as the nature of the constraints (pure rationing, too high price, too much demand of collateral) and the specific financing sources (banks, venture capital, etc.) the questions capture broadly several relevant aspects of innovation financing. Additionally, in our selection model, we consider a variable (demand finance) which represents the firms' general need for external capital to finance innovation projects. On a five-point Likert scale, firms were asked to rate the importance of external finance for their innovation activities (5: very high, 4: high, 3: medium, 2: low, 1: very low/none). We transformed it into a 


\begin{tabular}{|c|c|c|c|}
\hline Variable & Type & Description & 1 all \\
\hline \multicolumn{3}{|c|}{ Dependent variables } & \\
\hline & Dichotomous & Firm in need for external finance & \\
\hline Constraints & Dichotomous & Firms experienced finance constraints & \\
\hline \multicolumn{3}{|c|}{ Behavior: innovation intensity } & 297 \\
\hline $\begin{array}{l}\text { inno inc } c_{l n} \\
\text { inno } \text { rad }_{l n}\end{array}$ & $\begin{array}{l}\text { Continuous } \\
\text { Continuous }\end{array}$ & $\begin{array}{l}\text { Firms number of introduced incremental innovation, natural logarithm: } \ln (1+x) \\
\text { Firms number of introduced radical innovation, natural logarithm: } \ln (1+x)\end{array}$ & \\
\hline $\begin{array}{l}\text { Structure } \\
\text { size }_{\ln } \\
\text { age }\end{array}$ & $\begin{array}{l}\text { Continuous } \\
\text { Continuous }\end{array}$ & $\begin{array}{l}\text { Firms employees, natural logarithm: } \ln (x) \\
\text { Firms age in vears, natural logarithm: } \ln (x)\end{array}$ & \\
\hline \multirow{2}{*}{\multicolumn{4}{|c|}{ Conditions for innovation }} \\
\hline & & & \\
\hline imp tech & Dichotomous & Perception: high importance of access to technology & \\
\hline $\operatorname{imp} I P R$ & Dichotomous & Perception: high importance of IPR & \\
\hline imp market & Dichotomous & Perception: high importance of market knowledge & \\
\hline \multicolumn{4}{|l|}{ Controls } \\
\hline region met & Dichotomous & Firm located in a metropolitan region & \\
\hline industry & Categorical & Firm industry, (0) others, (1) manufacturing, (2) service, communication and finance & \\
\hline legal form & Categorical & Firm legal form, (0) others, (1) public traded, (2) limited liability & Table \\
\hline subsidiary & Dichotomous & Firm is a subsidiary & Variable descriptic \\
\hline
\end{tabular}

dichotomous variable taking the value of 1 for firms that report external finance to have at least some importance (value $>2$ ). We employ this variable in the first step of our analyses to take into account endogenous selection of firms seeking external finance, similar to the approach of Mina et al. (2013).

Independent variables. Behavioral variables: innovation intensity. In the survey, firms list whether they have introduced new products, processes or services that are either new only to the firm (incremental) or to the market/world (radical)[6] and if so, how many. In contrast with studies measuring innovation activities in a dichotomous way, we utilize this information on the number of introduced incremental and radical innovations to create a continuous measure of innovation intensity. While innovation is generally considered a source of information asymmetries, we expect this effect to soften with increasing innovation intensity. Firms that frequently engage in a high number of innovation projects are likely to develop routines to manage this process in a more structured way, which may be associated with increasing documentation and therefore higher transparency. Therefore, the variables incremental (inno inc) and radical (inno rad) innovation intensity are transformed by their natural logarithm in all regression models.

Structural characteristics: firm size and age. We include the firm-specific structural characteristics most commonly associated with financial constraints, size (in number of employees) and age (in years), to account for the possible effects of the "liability of newness" (Stinchcombe and March, 1965) and "liability of smallness" (Aldrich and Auster, 1986). However, once a firm develops a track record for a number of years, asymmetric information problems stemming from a lack of historical data are likely to be alleviated, and further benefits from ageing only manifest in possible reputation effects and increasing strength of the financier-firm relationship. We suggest the same pattern for size (Brancati, 2015), where at a certain size, legal disclosure requirements, and the establishment of professional finance and accounting management eliminate a substantial share of information asymmetries. To account for the assumed decreasing marginal impact as well as the skewness of the variable distribution, size and age also enter the regression models in their natural logarithm. 
Conditions for innovation. We further utilized the answers to additional questions on general opinions and impressions of the firm that might provide insights regarding the type of innovation likely to be produced. imp. tech represents a dummy variable taking a value of 1 if the firm believes that technological knowledge is of high or highest importance to its business (on a five-point Likert scale), indicating that the firm is technology based. imp. IPR relates to the firm's assessment of the importance of intellectual property protection, and is an indicator for more technology-based firms operating in an environment where innovation outcomes can be codified and protected. Finally, imp. market is about the belief that market knowledge is vital for the firm, indicating competitive, complex and changing market conditions.

Control variables. Region. The firm's environment is assumed to influence its access to external financing in other ways than indicated above. The regional setting in which the firms is embedded can make an impact (Lee and Brown, 2016). Consequently, we introduce categorical control variables for the firm's location on municipality level. Since the assessment of small, young and innovative firms can be facilitated by tacit knowledge exchange and social proximity, and since financial institutions tend to cluster in urban areas, we expect firms in less densely populated regions outside the Aalborg region, North Jutland's urban core, to be more likely to face financial constraints. Therefore, we include dummy variables indicating if the firm is located in the inner Aalborg metropolitan area (region met $_{\text {) }}$.

Industry. Firms in the manufacturing industry usually embody a higher share of tangible assets suitable to serve as collateral, and thus are favored by asset-based creditability evaluation techniques. Furthermore, production processes and their output may be better understood and valued than the somewhat intangible work of service firms. Therefore, we suggest, in accordance with earlier literature (Canepa and Stoneman, 2008), that industry affiliation matter to financial constraints, specifically that firms in the manufacturing industry to be less likely to face financial constraints. We introduce categorical control variables for the firm's industry affiliation (manufacturing, service, others).

Ownership structure and legal form. We also expect the firm's ownership structure to matter. More precisely, if it is a subsidiary, it may be nurtured by its parent company, and thus be less in need of external financing (Mina et al., 2013).

The firms' legal form makes them likely to differ in demand and access to external capital. Publicly traded companies have access to finance themselves on public capital markets and therefore have less demand for other sources of external financing than firms of other legal forms. Among privately owned businesses, we assume limited liability firms to be more likely to experience financial constraints than sole proprietorship, in which the firm's credit is backed by the private wealth of the entrepreneur.

\subsection{Descriptive statistics}

The refined data set represents an unbalanced panel containing 8,447 observations of 2,723 unique firms. Only a sub-population of firms was asked to answer the set of innovation and financial constraints-related questions relevant for this study, which leaves us with 2,822 observations of 1,169 unique firms, whose participation in the different survey waves ranges from 1 to 12 times, where about 25 percent of firms participated in 2 or fewer and 95 percent in 7 or fewer waves. In the rare cases $(<5$ percent of observations) of missing data on firm characteristics and survey question replies of the independent variables, we used multivariate imputation techniques.

Table II provides descriptive statistics at the firm level. A total of 63 percent of the firms in our sample express the need for external finance at all, while the remaining share prefer to finance innovation projects by internal means. A total of 30 percent of those in need of external finance report that they experienced financial constraints in external innovation finance in the corresponding observation period. The average firm has slightly fewer than 


\begin{tabular}{|c|c|c|c|c|c|c|}
\hline Variable & $N$ & Mean & SD & Min. & Max. & 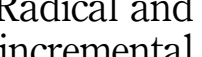 \\
\hline \multicolumn{6}{|c|}{ Dependent variables } & ratio \\
\hline Need finance & 2,822 & 0.63 & - & 0.00 & 1.00 & \\
\hline Constraints & 1.790 & $0.30^{\mathrm{a}}$ & - & 0.00 & 1.00 & \\
\hline \multicolumn{7}{|c|}{ Independent variables } \\
\hline size * ${ }^{*}$ & 2,822 & 49.78 & 95.79 & 1.00 & \multirow{2}{*}{$\begin{array}{r}1,600.00 \\
135.00\end{array}$} & 99 \\
\hline age* & 2,822 & 17.66 & 12.68 & 1.00 & & \\
\hline inno inc* & 2,822 & 4.06 & 10.60 & 0.00 & 100.00 & \\
\hline inno rad* & 2,822 & 1.59 & 6.30 & 0.00 & 99.00 & \\
\hline \multicolumn{7}{|c|}{ Control variables } \\
\hline imp tech & 2,822 & 0.09 & - & 0.00 & 1.00 & \\
\hline imp ipr & 2,822 & 0.09 & - & 0.00 & 1.00 & \\
\hline imp market & 2,822 & 0.23 & - & 0.00 & 1.00 & \\
\hline region $_{\text {met }}$ & 2,822 & 0.58 & - & 0.00 & 1.00 & \\
\hline subsidiary & 2,822 & 0.23 & - & 0.00 & 1.00 & \\
\hline
\end{tabular}

Notes: *For the sake of clarity, firm size (employees), age (years), incremental and radical innovation (count) are here displayed in full number and not in logarithmic transformation, which is used in the regression models; ${ }^{a}$ Baseline here are the firms in need for external finance

Table II. Descriptive statistics

50 employees and an age of about 17 years, where both variables are left skewed (cf. Figure 2). About a quarter of the firms consider knowledge on market conditions as crucial to their success, whereas only 9 percent think so regarding technological knowledge and IPR. Over 40 percent report that they introduced at least one product, process, or service new to the firm in the corresponding period. A slightly lower percentage introduced innovations new to the industry and the market, and roughly 70 percent planned to start new innovation projects in the next year. Firms introduced an average of 4.06 incremental and 1.59 radical innovations per firm and year. Figure 2 provides visual representation of the distribution and pairwise scatterplots between the numerical variables used.

The results of a bivariate analysis, presented in a pairwise correlation matrix in Table III, provide the first insights into the general interplay among innovation intensity, the need for financing, structural variables and financial constraints. As expected, size is negatively correlated with financial constraints, while surprisingly age does not. While incremental as well as radical innovation intensity is not associated with increased need for external finance, radical innovation intensity significantly correlates with financial constraints. However, no strong correlation indicating co-linearity can be found, as also confirmed by an analysis of the variance inflation factors of all variables in the used econometric models.

Table IV provides an overview on firm statistics by different size and age classes. On first glance our sample seems to be dominated by medium sized and medium aged companies, as to be expected[7]. With respect to financial needs as well as constraints, we see both to be higher for small as well as-even though less pronounced-for small firms. Old and large firms tend to introduce more incremental innovations. For radical innovation, that also holds for large firms, yet not for old, which in fact turn out to introduce radical innovation at a lower rate.

\subsection{Model setup and empirical strategy}

Our data set represents an unbalanced panel, where roughly half of the firms participated in 1 wave and the other half in 2-12, regressively developing. Accordingly, we deploy a pooled model and include year dummies to capture longitudinal variance of the effects. To address the issue of serial correlation among multiple observations of the same firm, we relax the assumption that standard errors are independently and identically distributed by clustering them at the firm level, which allows for within-group correlation. 
EJIM

23,2

Figure 2.

Distribution and scatterplot matrix
Table III.

Correlation matrix

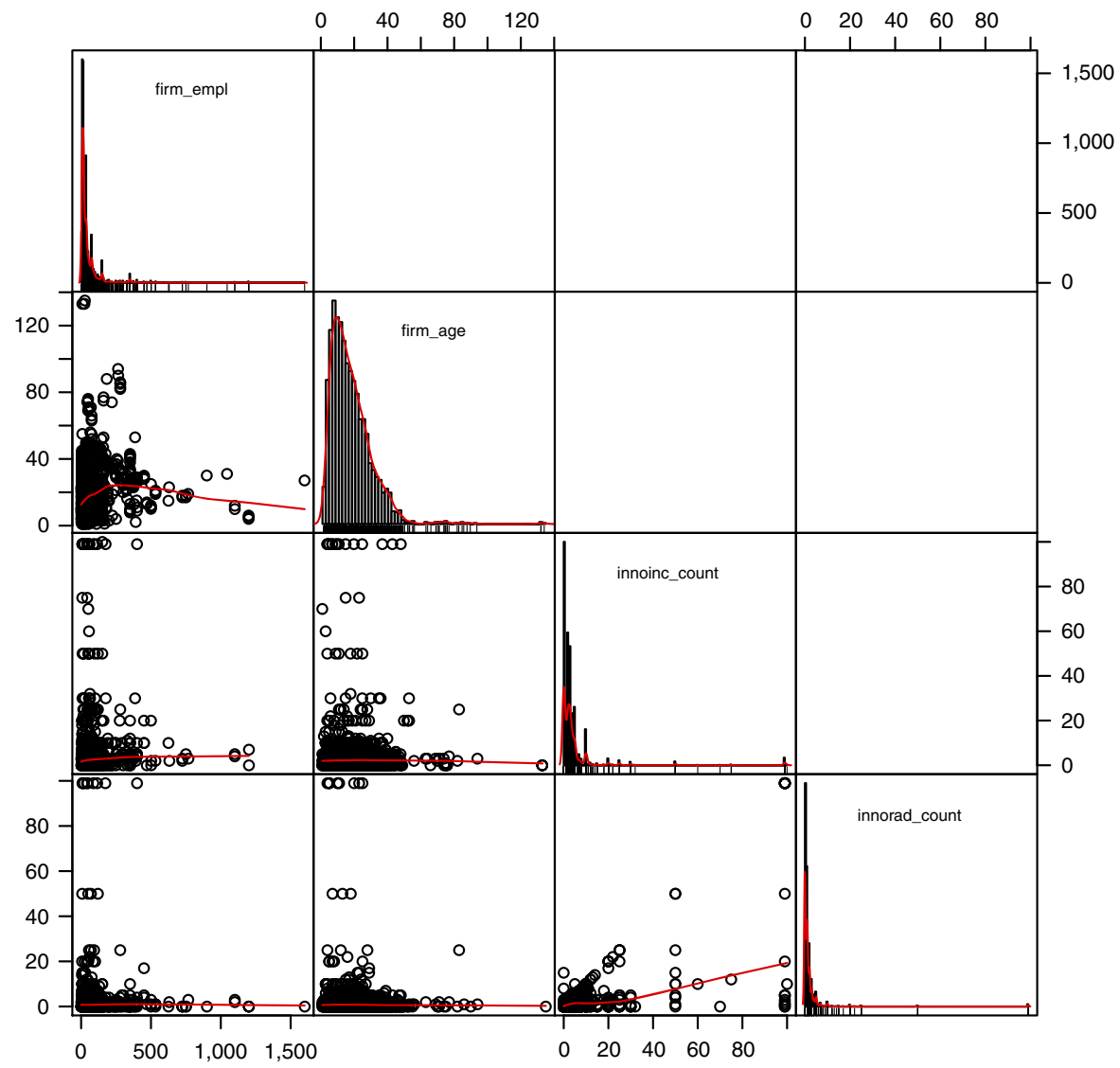

(1)

(2)

(3)

(4)

(5)

(6)

(7)

(8)

(9)

(10)

(1) Need finance

(2) Constraints

(3) region met

$0.455^{*}$

$-0.053-0.053$

(4) $\operatorname{size}_{l n}$

(5) $a g e_{l n}$

$\begin{array}{lll}-0.030 & -0.085^{*} & -0.052\end{array}$

(6) subsidiary

$\begin{array}{lll}-0.042 & -0.034 & -0.019\end{array}$

$-0.113 *-0.074 * 0.043$

$\begin{array}{lll}0.038 & 0.070^{*} & 0.019\end{array}$

(7) inno inc

0.021

$0.262^{*}-0.001$

$-0.000$

0.002

0.020

0.040

0.034

$0.039 * 0.003$

$0.002 \quad 0.055$

(11) imp market

0.003

$0.218^{*}$

$0.031 \quad 0.039$

$\begin{array}{lll}0.186 * & 0.051 & 0.002\end{array}$

$-0.030-0.037 *$

$\begin{array}{lll}0.004 & 0.009 & -0.014\end{array}$

$-0.065^{*}-0.034$

$\begin{array}{ll}0.027 & 0.004\end{array}$

0.038

0.017

$0.098 * 0.138 *$

$0.0480 .104^{*} 0.243^{*}$

Note: $* p<0.01$, two-tailed Pearson correlation

The dichotomous nature of our dependent variable and the very nature of our survey data suggest the use of a probit model. To analyze the interplay between supply and demand for external financing for innovation, we chose a two-stage model with endogenous selection, which allowed us to construct a consistent model for decisions both to seek and to obtain 


\begin{tabular}{|c|c|c|c|c|c|c|c|}
\hline \multirow[b]{2}{*}{ Variables } & \multicolumn{3}{|c|}{ By firm size (empl.) } & \multicolumn{3}{|c|}{ By firm age (years) } & \multirow{2}{*}{$\begin{array}{l}\text { Radical and } \\
\text { incremental }\end{array}$} \\
\hline & $\leqslant 50$ & $51-100$ & $>100$ & $\leqslant 10$ & $11-25$ & $>25$ & \\
\hline$\%$ & 0.76 & 0.14 & 0.10 & 0.33 & 0.46 & 0.21 & \\
\hline Need finance & 0.64 & 0.62 & 0.60 & 0.65 & 0.62 & 0.63 & \\
\hline Constraints & 0.32 & 0.31 & 0.16 & 0.33 & 0.29 & 0.30 & \\
\hline size* & 19.21 & 73.65 & 249.89 & 37.65 & 47.32 & 79.00 & \\
\hline age* & 16.01 & 20.67 & 25.02 & 6.56 & 17.18 & 35.95 & 301 \\
\hline inno inc* & 3.74 & 6.62 & 7.03 & 4.44 & 4.03 & 4.12 & \\
\hline inno rad* & 1.65 & 2.27 & 3.18 & 2.14 & 2.02 & 1.21 & \\
\hline imp tech & 0.09 & 0.08 & 0.09 & 0.08 & 0.10 & 0.09 & \\
\hline$i m p i p r$ & 0.09 & 0.08 & 0.11 & 0.10 & 0.10 & 0.07 & \\
\hline imp market & 0.22 & 0.26 & 0.32 & 0.23 & 0.24 & 0.24 & \\
\hline region $_{\text {met }}$ & 0.59 & 0.57 & 0.52 & 0.58 & 0.58 & 0.59 & \\
\hline subsidiary & 0.15 & 0.14 & 0.24 & 0.10 & 0.19 & 0.15 & Tabl \\
\hline $\begin{array}{l}\text { Note: *For th } \\
\text { here displayed }\end{array}$ & $\begin{array}{l}\text { larity } \\
\text { umber }\end{array}$ & $\begin{array}{l}\text { (emplo } \\
\text { in logar }\end{array}$ & $\begin{array}{l}\text { (years), } \\
\text { insform }\end{array}$ & $\begin{array}{l}\text { ental an } \\
\text { hich is }\end{array}$ & $\begin{array}{l}1 \text { innovat } \\
\text { the regre }\end{array}$ & $\begin{array}{l}\text { unt) are } \\
\text { nodels }\end{array}$ & $\begin{array}{l}\text { Cross-tabulations: } \\
\text { size and a }\end{array}$ \\
\hline
\end{tabular}

financing for innovation projects, where the former obviously represents the prerequisite for the latter. This is done with a technique equivalent to the well-established two-stage Heckman correction in linear models (Heckman, 1979), applied for bivariate probit models (Van de Ven and Van Praag, 1981) and estimating a firm's likelihood to experience financial constraints by full maximum likelihood. We use the same variables to estimate the likelihood of being in need of external finance and also to experience financial constraints, while we add an additional "exclusion restriction" in on the first stage. Here, we follow Mina et al. (2013) by utilizing the information if the firm is a subsidiary, which could be financially supported by the parent company.

We execute our econometric analysis as follows. Model 1 includes control variables for the corresponding year, the firm's industry affiliation and its legal form, some basic firm characteristics, its incremental and radical innovation intensity (H1a and H1b), and its perceived importance of some factors associated with innovation. In model 2 , we add an interaction term between the firms' incremental innovation intensity and its structural characteristics size and age (inc. inno*size $e^{-1}$, inc. inno*age ${ }^{-1}$ ). To test the interplay between innovation intensity and the liability of newness and smallness, we reverse the magnitude of both age and size to have high values for young and small firms, and vice versa. We do the same in model 3 for radical innovation intensity $\left(\mathrm{rad}_{\text {. inno }}\right.$ size $^{-1}$, $\mathrm{rad}_{\text {. inno* }}$ age $\left.^{-1}\right)$. In both models, we test if young and small firms are over-proportionally affected by the assumed negative impact of innovation intensity on the access to external finance (H2a), and by their comparison if the type of innovation activity matters $(H 2 b)$.

\section{Results}

\subsection{Regression results}

The results of the two stage Heckman Probit model for endogenous selection are reported in Table $\mathrm{V}$, where we fit a model that predicts the probability of a firm to experience financial constraints (second stage), conditional to its need for external finance.

Even though the first stage is not of main interest for our analysis, it is necessary for endogeneity reasons and results may be interesting in themselves. We, however, in the following focus on the results of the second stage, where we test the firm's likelihood to experience financial constraints. In model I, we see that size matters to obtaining financing, as increasing size reduces the chances of being constrained, significant at least at the 1 percent level. In line with $H 1 a$ and $H 1 b$, radical innovation intensity is associated with a higher 


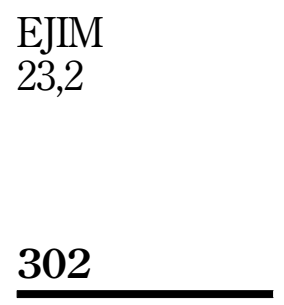

Table V.

Regression table probit model with endogenous selection

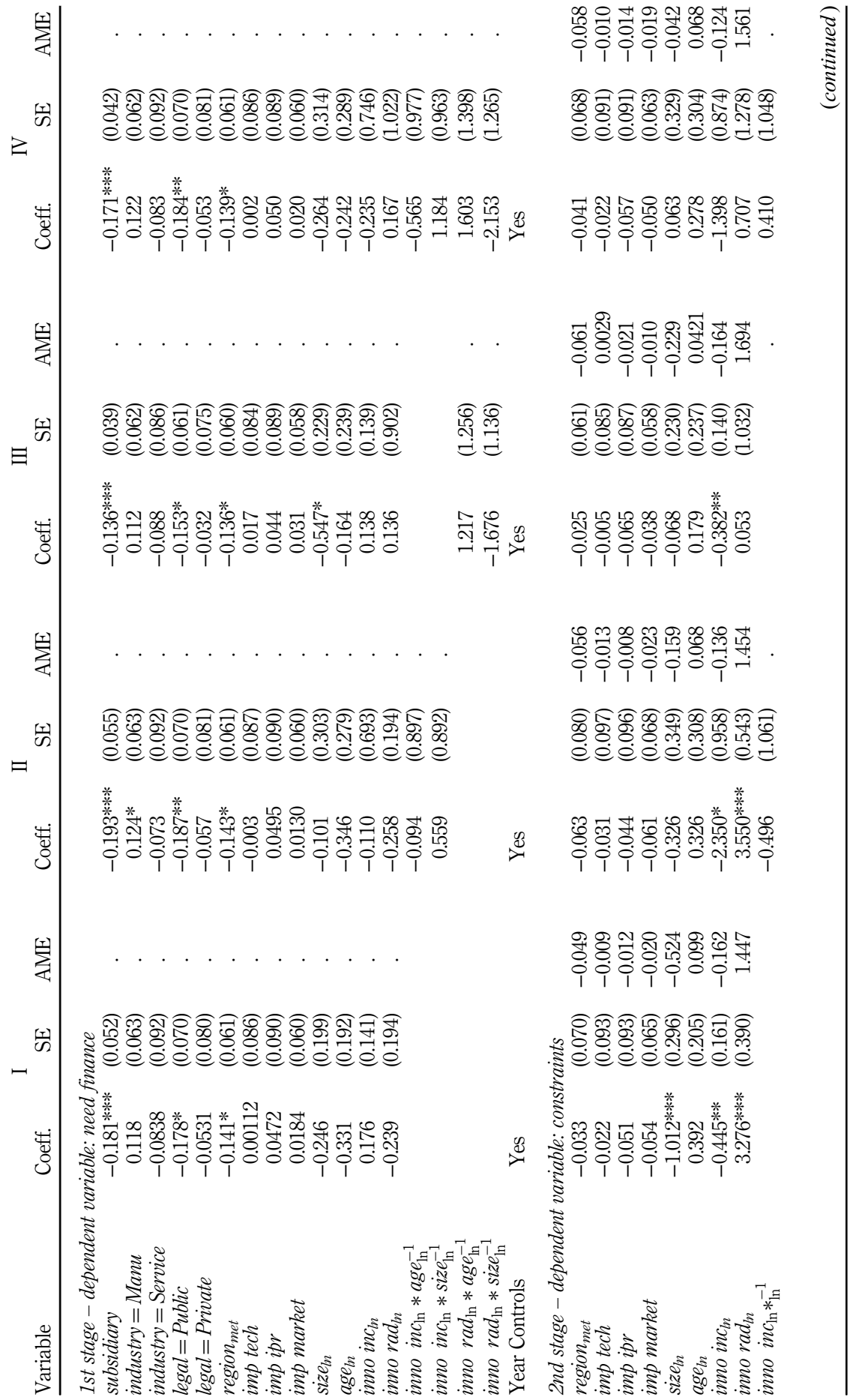




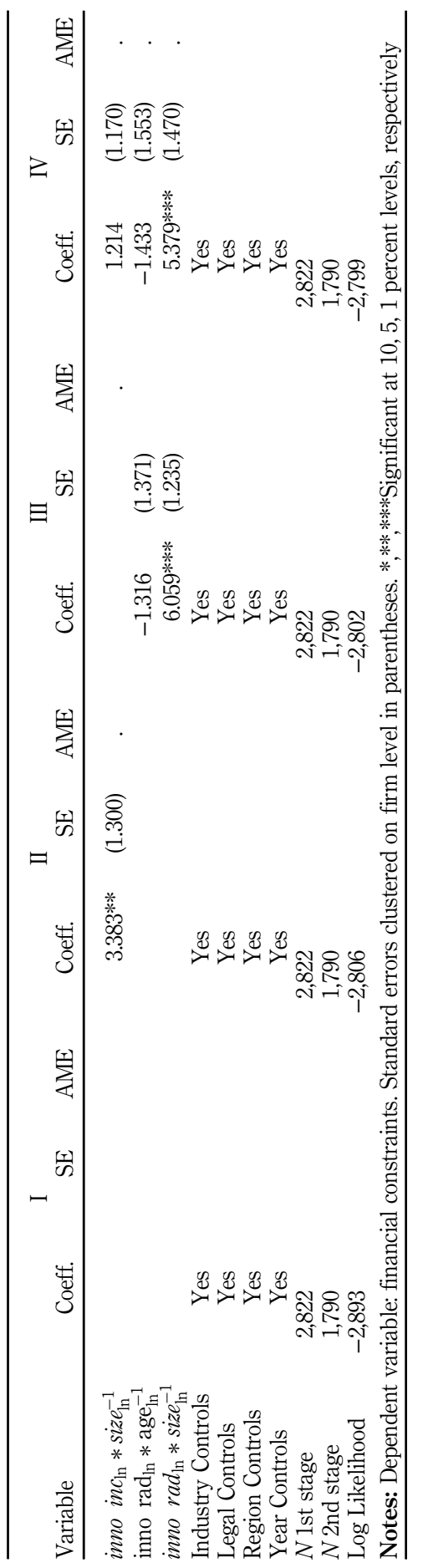

Radical and incremental innovation

303 
EJIM

23,2

304

probability of being financially constrained, also significant at the 1 percent level. This is not true for incremental innovation, which is also significant (5 percent), but against initial expectation shows a negative but not significant coefficient, lending support to $H 1 b$, and at the same time calling for more nuanced understanding of the relationship between different types of firm level innovation activities and financial constraints (Brander et al., 2002).

In model II, we introduce interaction terms with the structural characteristics age and size and the behavioral variable (innoinc ${ }_{m}^{*} \operatorname{size}^{-1}$, innoinc ${ }_{l n}^{*} a g e^{-1}$ )[8]. Here, results spur some interesting observations. First, the magnitude of the effect of age on the likelihood of experiencing financial constraints sharply declines, and turns insignificant. Incremental innovation intensity decreases in intensity, now on the 10 percent level. In contrast, the interaction term between incremental innovation intensity and the liability of smallness shows a high and positive coefficient, significant at the 5 percent level, indicating in favor of $H 2 a$ that high innovation intensity and smallness indeed amplify each others negative effect on access to external finance. We yet do not find a significant effect of being young and at the same time displaying a high innovation intensity, leading to a partial rejection of $H 2 a$. In combination of the bivariate analysis (cf. Table III, where age positively correlates with radical and more so with incremental innovation), that indicates financial constraints with respect to age to be an outcome of heterogeneous innovation activities across age classes[9].

In Figure 3, we plot the estimated average marginal effect of incremental and radical innovation intensity against different levels of the liability of smallness and newness. In the

(a)

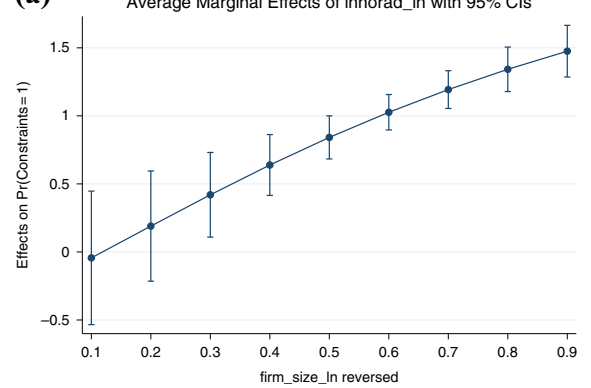

(c)

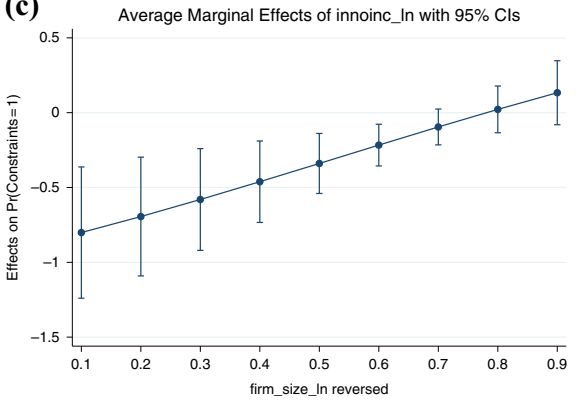

(b) Average Marginal Effects of innorad_ln with $95 \%$ Cls

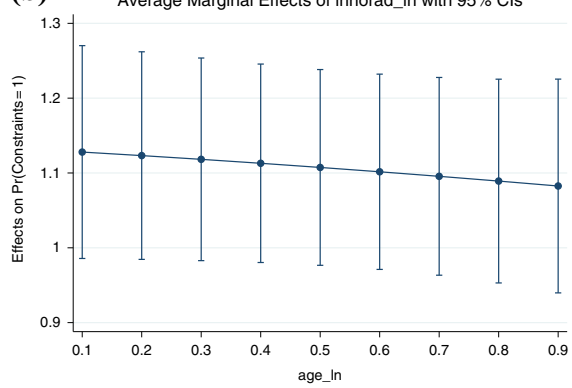

(d) Average Marginal Effects of innoinc_In with $95 \% \mathrm{Cls}$

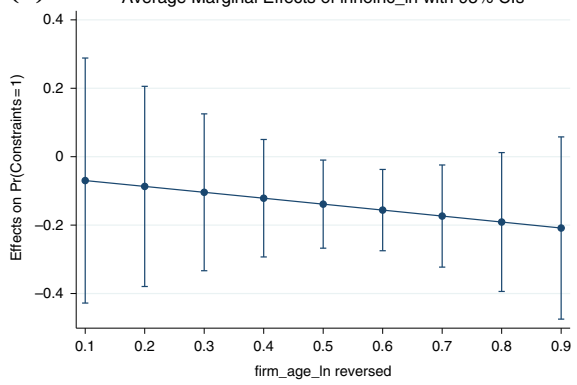

Figure 3.

Average marginal effect (AME) of firm size and age with respect to innovation activity
Notes: The plots for incremental innovation refer to the second stage of model II, for radical innovation refer to the second stage of model III. In the interaction term, both the logarithmic measure for firm age and size are reversed in order to capture the liability of newness and liability of smallness. (a) AME of radical innovation by liability of smallness; (b) AME of radical innovation by liability of newness; (c) AME of incremental innovation by liability of smallness; (d) AME of incremental innovation by liability of newness 
lower row, we see that incremental innovation intensity decreases the likelihood of experiencing financial constraints in the case of large firms, while this effect increasingly vanishes for smaller firms (left side). Consequently, financial markets appear to reward incremental innovation with a premium access to capital, while being agnostic for such activity in the case of small firms. The effect of age (right side), however, is less conclusive. While the marginal effects of incremental innovation conditional to firm age for the most part are not significantly different from zero, for a small range of medium old firms incremental innovation appears to decrease the likelihood of experiencing financial constraints. In conclusion, our results indicate large firms to actually be rewarded by providers of external capital for engaging in incremental innovation activity, which are in turn agnostic regarding similar activity in small firms, and do not exhibit strong preferences across age classes.

In model III we introduce interaction terms of again the firm's age and size with its intensity in radical innovation activity $\left(\right.$ innorad $\left._{l n}\right)$. Interestingly, when introducing the interaction term, the main effect of radical innovation intensity on financial constraints vanishes in coefficient size as well as significance, while the main effect of incremental innovation activity remains negative and significant. While like in the former model the interaction term with the liability of newness remain insignificant, the one with the liability of smallness is significant at the 1 percent level, and shows the highest coefficient so far with almost twice the magnitude of the interaction with incremental innovation activity in the former model. Indeed, financiers appear to be far more sensitive toward radical compared to incremental innovation. In Figure 3, we see the estimated average marginal effect to be close to zero for very big firms, while progressively increasing the likelihood of experiencing financial constraints for smaller firms. In contrast to the results on incremental innovation, there appears to be no upside to radical innovation activity with respect to access to capital. While the effect for small firms is strongly negative, it in the best case becomes insignificantly different from zero for very large firms. As already indicated by the coefficient, no significant effect across age classes can be found. This result also holds when we in model IV test for all interaction terms jointly[10]. In summary, size enables firms to compensate for the negative effect of radical innovation activity, but not more. This, however, does not hold true for age.

\subsection{Robustness tests}

To evaluate the robustness of our findings, we carried out additional robustness tests. First, we test for omitted time-invariant variables on firm level by running both the finance demand (first stage) and supply model (second stage) separately deploying a fixed effects probit model. For our structural and innovation variables, we also tried different transformations (other than the here applied logarithmic one) such as the square-root, and also the non-transformed terms. Further, we ran a set of models where we replaced our continuous variables for innovation intensity with the traditionally used dichotomous version. Our variable indicating demand for finance (selection criterion on the first stage) was derived from a 1-5 Likert scale, where we classified firms answering with 2 or higher (access external finance of some importance for the company). We repeated the analyses with an adjusted threshold of 3 or 4 (medium-high importance). While the results remain similar, this led to an incomplete overlap between firms in need of finance and firms that report financial constraints, meaning that some firms report being constrained but are classified as in no need for external finance.

To control for the effect of the firm's financial performance on access to external finance, we additionally run all models including the firms self-assessed current and future profit expectations. Interestingly enough, these variables turned out to be insignificant in all cases, and did not distort the basic results. To account for possible optimism or pessimism biases caused by the firm's own evaluation of profits, we also replaced the self-reported profits with

Radical and incremental innovation 
EJIM

23,2

306

balance sheet data from Danish register data (which is unfortunately only available for a subset of firms). While mostly not as pronounced, all results point in a similar direction.

The period we analyze span across the financial crisis and it can be presumed that this has an effect on conditions for obtaining external finance (Cowling et al., 2012, 2018; Lee et al., 2015; Vermoesen et al., 2009). In our empirical analyses, we included year dummies to capture potential effects from changes in business cycles but additionally we introduced a number of macroeconomic business cycle indicators but found no effect on the main findings from this.

Since in our sample small as well as large firms are slightly over-represented, we re-ran all our models with bootstrapped (jackknife, 500 rep.) standard errors to adjust for potential sampling issues, also ran a model adjusted by population weights, and finally a model where we re-sampled our data to have a distribution of firm size in line with the corresponding Danish CIS data. All those measures led to almost identical results. All robustness tests remain unreported, but are available on request.

\section{Discussion}

While financiers seem to generally cope with "new-to-the-firm" incremental innovation and even reward them with higher access to external finance, more radical and uncertain "newto-the-world" activities appear to deter them. As we discuss in more detail in the concluding section this result can be seen in light of the results of Beck et al. (2016) who find that public funding schemes show higher additionality when supporting radical innovation rather than incremental innovation. Indeed, as Grilli et al. (2018) emphasize, the literature on evaluating $\mathrm{RD}$ investments has perhaps been too pre-occupied with short-term, narrow input additionality compared to investments in broader mission-oriented projects, which in turn are likely to need radical innovation. Financiers might be more willing to accept incremental endeavors close to what is already known on the market, but be deterred by more radical and technology-based ones (Howell, 2016; Mina et al., 2013; Westhead and Storey, 1997). Similar arguments apply to the internal processes within firms where management decides on which innovation projects are funded and which are closed. Firms may realize that in addition to external barriers there are too many internal or external financial barriers and financial sources that over the life cycle of an innovation project may cause firms to abandon innovation projects (García-Quevedo et al., 2018). Relatively few quantitative studies survey internal financial barriers but in particular for large firms we propose that similar mechanisms apply as with external finance.

On a more detailed level of aggregation we found strong evidence for the liability of smallness hypothesis, but not for liability of newness. Although several studies point to that age impact financial constraints, some studies contrast this and find no evidence for the impact of age on financial constraints. For example, Brancati (2015) similarly find strong evidence for size, but not for age. This spur questions around which structural variables are important to financiers when assessing funding of innovative firms. One possible explanation to this result is that financiers value collateral, which is more likely to be in larger firms.

A final point for discussion is whether results are highly contextual in time. In the aftermath of the financial crisis there are indications that investors are avoiding long-term, radical innovation projects (Grilli et al., 2018; Paunov, 2012), and firms may likewise abstain from radical innovation. The potential reluctance to finance radical innovations may have consequences for the speed and direction of future firm-level growth paths as well as societal technological changes (Dosi, 1990; King and Levine, 1993; Mazzucato, 2013; Mazzucato and Semieniuk, 2018; Tylecote, 2007).

\section{Conclusion}

In this study, we build on previous theories and studies on demand and constraints for financing for different types of firms and add new, improved ways of analyzing this 
problem area. Our hypotheses were built to render a more nuanced picture of the financial constraints problem than has been presented to date. We were able to analyze this problem area using longitudinal data, and our overall results are both congruent with and in contrast to some previous findings in the literature.

It has been claimed that by and large firms who apply for credit gets it (Nightingale and Coad, 2014) but that some types of firms may be financially constrained. Regarding the demand side our results indicate weak systematic patterns in which types of firms are demanding external finance. Unsurprisingly, the variable on realized, positive economic results decreases demand for external finance as does the firms' status as subsidiary. We thereby find evidence in favor of the "pecking order" theory of corporate finance (Myers and Majluf, 1984), indicating firms to generally favor internal over external sources of capital to fund their innovation activities.

Our analysis on the perceived constraints on external capital (supply) revealed - besides further evidence for the "liability of smallness" but not "newness" - that the effect of innovation per se on capital demand and supply is not uniform, but rather interdependent with other firm characteristics. Firm size generally tends to the negative consequences of firm level innovation activity on the access to capital, or even turn them into a positive effect. However, financier appears to be indifferent with respect to firm age. We first and foremost find that the type of innovation, and not only the amount of innovative activity, matters. While incremental innovation by and large is rewarded by financiers, the results for more radical innovations are more ambiguous but generally indicate that these types of innovation are harder to fund from external sources. This appears to be particularly prevalent for small radical innovators.

Our findings provide implications for policy, innovation management and theory alike. First, they lead us to question the generalization of existing theories in the field. Whereas financial markets are often seen as prime examples of markets with full information and extended mobility of production factors, our results indicate that the demand and supply of finance nexus is nuanced and highly contextual. Most importantly, we find evidence that not only the quantity, but also the quality of a firm's innovation activity matters for their access to external capital. While we find no negative effect of incremental innovation, technology-based and radically innovating firms are constrained. This is congruent with some earlier studies that posit that "some, not too much, innovation is good" (Freel, 2000, 2007). We, however, add to the discussion that it is less about how much, but more about how radical a firm innovates. We further identify an interaction between a firms innovation intensity and its size, as small innovators are particularly penalized by capital markets.

Second, our findings may inform policy makers designing public funding schemes to facilitate private sector innovation activities. We provide evidence on which characteristics make innovative firms more likely to be financially constrained. While leaving the question of productivity and "value for money" (e.g. Czarnitzki and Lopes-Bento, 2013) of funding schemes open[11], our research points toward that the target group of such schemes is an important, integral part of their rationale. Most public support programs for access to financing place restrictions on eligibility; most often their financing is available only to firms that are young, small, innovative or some combination thereof. The results of our study indicate a need for careful consideration of these eligibility criteria. For example, many programs aim at increasing the number of innovative firms by way of, e.g., subsidizing access to knowledge for non-innovative firms ("innovation vouchers" and similar programs). We emphasize that not only being innovative per se, but the quantity as well as quality of innovative activity matters for firms' access to capital. Former empirical evidence shows that public policy support programs have different effects on incremental compared with radical innovation activities (Beck et al., 2016). We point out that radical innovators are often credit rationed and constrained, which in turn means that policy programs facilitating 
EJIM

23,2 radical innovation are in need of sensible consideration. The speed and direction of technological change is dependent upon radical innovation and as discussed in the introduction, the private investors and within-firm management are often reluctant to go into long term, radically new projects. It could therefore be considered if public policy programs should to a larger extent be designed toward addressing this need. In terms of policy targeting, we hint to the need to particularly support radical but small innovators. Related, the rationale and impact of innovation financing policies is discussed in relation to how innovation can contribute to tackling some of the grand societal challenges like climate change, development of health technologies, etc. (Grilli et al., 2018). Radical innovations can be argued to be crucial in this connection, but might, according to our results, face particular financing problems. This is not only due to the radical nature of innovations, also because these types of problems require public-private partnerships.

Third, the results point to a number of implications for management. One is the financing aspects of the classic ambidexterity challenge for management (March, 1991) and to find this balance while considering the available resources. Striking the right balance between incremental and radical innovation is an important management issue where both conservatism and overoptimism are risky strategies. Earlier literature has primarily discussed the needed resources as internal human and financial capital, and organizational capabilities. We add an external finance perspective to this discussion. The fact that radical innovation seems more difficult to fund externally introduces an additional nuance to this choice for innovation managers. Moreover, and linked to the point made above on pecking order theory, we posit that managers can have different preferences for finance depending on which type of project is in need of finance. For radical innovation the preferences for internal finance may be stronger because of the external financing difficulties (and -prices), whereas incremental innovation projects will find the external financing market attractive. Additionally, we do not find evidence of liability of newness, which implies that managers in new firms should not be reluctant to seek external innovation financing, even if they do not have a long track record. This parameter seems of less importance in credit assessment compared to the type of innovation, size of the firm and collateral. Finally, in the entrepreneurial finance literature it is discussed that a relatively large proportion of firms (managers) are discouraged borrowers, that is, may have a need for external finance but abstain from entering the capital market in the anticipation that they will be rejected (Kon and Storey, 2003). As the majority of other studies on financial constraints we neglect firms without articulated need for external capital (Freel et al., 2012; Han et al., 2009; Kon and Storey, 2003). The decision to not enter the market for external finance is based on expectations regarding how capital markets react. In turn, these expectations are grounded in more or less solid information and knowledge. We realize that there is a long way from averages presented here to actual, individual cases, but the results nevertheless inform managers on what to expect regarding how capital markets assess innovation projects.

A number of limitations apply to this study and hence how far we can go in drawing universally valid conclusions. The study was confined to a small region in a small country. Although this region is known for having both incremental and radical innovation (e.g. a strong mobile communications cluster of firms) then entrepreneurial finance is to a large extent contextual (Ning et al., 2015), and the results may to some extent have been different in another financial system. Another limitation is that, as in other CIS-like studies, we do not include very small firms as we survey firms with a minimum of five employees. Moreover, although we include a broader sample than many other studies we over-sample manufacturing sector firms. We also treated financiers and types of financing as if they were homogeneous. Although it is also a strength of the present study to encompass a wide array of financing sources in one, in reality there are vast differences between, for example, 
venture capital and bank financing, and somewhat different results might be seen if the analyses were confined to only one type of capital (Brown et al., 2012). The above-mentioned limitations and remarks on theories indicate possible directions for future studies. Despite being extensively studied over the past 100 years, studies of financing innovation is still in need of more nuances, for example, differentiating between different types of external capital and different types of providers. Although the CIS data and SAFE-data have improved our statistical knowledge, we furthermore point to the need in future studies to build data that allow use of a more nuanced dependent variable. The present study goes some of the way toward this objective, but additional knowledge on financial constraints could be made possible if more knowledge and data were available on, e.g., internal/external financing constraints, partly fulfilled financing needs and specifics of the purpose of funding applications.

\section{Notes}

1. Though lack of finance is often highlighted as a major barrier to business development (Bottazzi et al., 2014; Musso and Schiavo, 2008), the mere existence as well as economic significance of credit rationing, and so-called debt gaps for SMEs, is also contested by others (Berger and Udell, 2003; Cressy, 2012; Levenson and Willard, 2000).

2. The operationalization of the variables named there is explained in Section 3.

3. The surveyed firms account for around 30 percent of employment in the region. The total population of North Jutland is around 600,000 people.

4. The innovation survey for Denmark shows that the shares of innovative firms in the same industries as we study are 42 and 43 percent in 2014.

5. For further background on firms' access to external capital in Denmark's North Jutland region, consider Christensen (2007).

6. This distinction is in line with what is commonly used in innovation studies using CIS surveys. Like in CIS, the innovation activities are self-reported. This means that there might be a bias in the perceptions respondents have regarding whether their new products, services or processes are new to the world/market or not. Moreover, the fact that an innovation is perceived as new to the world/market does not necessarily imply that it has a radical impact. In CIS, R\&D is included in the innovation definition rendering an additional, potential bias as respondents will not know ex ante if $\mathrm{R} \& \mathrm{D}$ will lead to radical now innovation. We avoid this bias by not having R\&D activity as part of the innovation definition. Furthermore, while broadly in line with the working definition in the CIS, our interpretation of introducing products and processes new to the firm as incremental innovation is also debatable. Arguably, this could also be interpreted as adaption rather than innovation. Yet, while slightly altering the interpretation of our results, this perspective ultimatively leads to the same conclusions.

7. Indeed, the distribution of firm size is roughly in line with the ones for the whole Danish firm population according to official statistics by Denmark's statistical bureau. This holds for the distribution across industries (NACE classes included in the survey) as well as age. For firm size, however, we notice a slight (between $+3-5$ percent across the different waves) of small (ten employees) and large ( $>100$ employees) firms, which might lead to slightly stronger results for the size effect.

8. The $x^{-1}$ superscript indicates the variable to be reversed, so that originally highest values now represent the lowest ones, and vice versa. The reason for doing so is to explicitly test for the interaction between innovation intensity and the liability of newness and smallness. Thus, high values of size $e^{-1}$ and $a g e^{-1}$ indicate the firm to be comparably small or young.

9. Note also that in an unreported (but available on request) model, we only use the control variables, without the ones capturing innovation activity. Here, we see some significance (5 percent level) for the coefficient of age.
Radical and incremental innovation 
10. In further unreported (but available on request), we also introduce interaction terms between age and size, as well as three-way interactions between age or size with inno inc*inno rad. Those, however, all remain insignificant.

11. Cf. Grilli et al. (2018) for a review of recent advances in this area.

\section{References}

Akerlof, G.A. (1970), “The market for lemons: quality uncertainty and the market mechanism”, The Quarterly Journal of Economics, Vol. 84 No. 3, pp. 488-500.

Aldrich, H. and Auster, E.R. (1986), "Even dwarfs started small: liabilities of age and size and their strategic implications", Research in Organizational Behavior, Vol. 8, pp. 165-198.

Beck, M., Lopes-Bento, C. and Schenker-Wicki, A. (2016), "Radical or incremental: where does R\&D policy hit?”, Research Policy, Vol. 45 No. 4, pp. 869-883.

Beck, T. and Demirguc-Kunt, A. (2006), "Small and medium-size enterprises: access to finance as a growth constraint", Journal of Banking \& Finance, Vol. 30 No. 11, pp. 2931-2943.

Berger, A., Klapper, L. and Udell, G. (2001), "The ability of banks to lend to informationally opaque small businesses", Journal of Banking \& Finance, Vol. 25 No. 12, pp. 2127-2167.

Berger, A.N. and Udell, G.F. (2003), "Small business and debt finance", in Acs, Z.J. and Audretsch, D.B. (Eds), Handbook of Entrepreneurship, Kluwer, Dordrecht, pp. 299-328.

Bottazzi, G., Secchi, A. and Tamagni, F. (2014), "Financial constraints and firm dynamics", Small Business Economics, Vol. 42 No. 1, pp. 99-116.

Brancati, E. (2015), "Innovation financing and the role of relationship lending for SMEs", Small Business Economics, Vol. 44 No. 2, pp. 449-473.

Brander, J.A., Amit, R. and Antweiler, W. (2002), "Venture-capital syndication: improved venture selection vs the value-added hypothesis", Journal of Economics \& Management Strategy, Vol. 11 No. 3, pp. 423-452.

Brown, J.R., Martinsson, G. and Petersen, B.C. (2012), "Do financing constraints matter for R\&D?", European Economic Review, Vol. 56 No. 8, pp. 1512-1529.

Canepa, A. and Stoneman, P. (2008), "Financial constraints to innovation in the UK: evidence from CIS2 and CIS3", Oxford Economic Papers, Vol. 60 No. 4, pp. 711-730.

Canton, E., Grilo, I., Monteagudo, J. and Van der Zwan, P. (2013), "Perceived credit constraints in the European Union”, Small Business Economics, Vol. 41 No. 3, pp. 701-715.

Carpenter, R. and Petersen, B. (2002), "Capital market imperfections, high-tech investment, and new equity finance", The Economic Journal, Vol. 112 No. 477, pp. F54-F72.

Carreira, C. and Silva, F. (2010), "No deep packets: some stylized empirical results on firms?”, Journal of Economic Surveys, Vol. 24 No. 4, pp. 731-753.

Chatzoglou, P. and Chatzoudes, D. (2018), "The role of innovation in building competitive advantages: an empirical investigation”, European Journal of Innovation Management, Vol. 21 No. 1, pp. 44-69.

Christensen, J. (2007), "Constraints on innovation finance in North Jutland, Denmark", European Planning Studies, Vol. 15 No. 9, pp. 1163-1180.

Colombo, M. and Grilli, L. (2007), "Funding gaps? Access to bank loans by high-tech start-ups", Small Business Economics, Vol. 29 No. 1, pp. 25-46.

Cowling, M., Liu, W. and Ledger, A. (2012), "Small business financing in the UK before and during the current financial crisis", International Small Business Journal, Vol. 30 No. 7, pp. 778-800.

Cowling, M., Liu, W. and Zhang, N. (2018), "Did firm age, experience, and access to finance count? SME performance after the global financial crisis", Journal of Evolutionary Economics, Vol. 28 No. 1, pp. $77-100$. 
Cressy, R. (2012), The Oxford Handbook of Entrepreneurial Finance, chapter Funding Gaps, Oxford University Press, Oxford, pp. 255-304.

Czarnitzki, D. and Lopes-Bento, C. (2013), "Value for money? new microeconometric evidence on public R\&D grants in Flanders", Research Policy, Vol. 42 No. 1, pp. 76-89.

Radical and incremental innovation

D'Este, P., Iammarino, S., Savona, M. and von Tunzelmann, N. (2012), "What hampers innovation? Revealed barriers versus deterring barriers", Research Policy, Vol. 41 No. 2, pp. 482-488.

Das, P., Verburg, R., Verbraeck, A. and Bonebakker, L. (2018), "Barriers to innovation within large financial services firms: an in-depth study into disruptive and radical innovation projects at a bank", European Journal of Innovation Management, Vol. 21 No. 1, pp. 96-112.

Dosi, G. (1990), "Finance, innovation and industrial change", Journal of Economic Behavior \& Organization, Vol. 13 No. 3, pp. 299-319.

Dosi, G. and Orsenigo, L. (1988), "Coordination and transformation: an overview of structures, behaviours and change in evolutionary environments", in Dosi, G., Freeman, C., Nelson, R. and Soete, L. (Eds), Technical Change and Economic Theory, Pinter Publishers, London, pp. 13-37.

Fazzari, S., Hubbard, R.G., Petersen, B.C., Blinder, A.S. and Poterba, J.M. (1988), "Financing constraints and corporate investment", Brookings Papers on Economic Activity, Vol. 1 No. 1, pp. 141-195.

Freel, M. (2000), "Barriers to product innovation in small manufacturing firms", International Small Business Journal, Vol. 18 No. 2, pp. 60-80.

Freel, M. (2007), “Are small innovators credit rationed?”, Small Business Economics, Vol. 28 No. 1, pp. 23-35.

Freel, M., Carter, S., Tagg, S. and Mason, C. (2012), "The latent demand for bank debt: characterizing discouraged borrowers", Small Business Economics, Vol. 38 No. 4, pp. 399-418.

García-Quevedo, J., Segarra-Blasco, A. and Teruel, M. (2018), "Financial constraints and the failure of innovation projects", Technological Forecasting and Social Change, Vol. 127, pp. 127-140.

Giudici, G. and Paleari, S. (2000), "The provision of finance to innovation: a survey conducted among Italian technology-based small firms”, Small Business Economics, Vol. 14 No. 1, pp. 37-53.

Grilli, L., Mazzucato, M., Meoli, M. and Scellato, G. (2018), "Sowing the seeds of the future: policies for financing tomorrow's innovations", Technological Forecasting and Social Change, Vol. 127, pp. 1-7.

Hall, B.H. (2010), “The financing of innovative firms”, Review of Economics and Institutions, Vol. 1 No. 1, pp. 1-30.

Han, L., Fraser, S. and Storey, D. (2009), "Are good or bad borrowers discouraged from applying for loans? Evidence from us small business credit markets", Journal of Banking \& Finance, Vol. 33 No. 2, pp. 415-424.

Häussler, C., Harhoff, D. and Müller, E. (2014), "How patents inform VC investors-the case of biotechnology", Research Policy, Vol. 43, pp. 1286-1298.

Heckman, J.J. (1979), "Sample selection bias as a specification error", Econometrica: Journal of the Econometric Society, Vol. 47 No. 1, pp. 153-161.

Hollanders, H. and Es-Sadki, N. (2017), "European innovation scoreboard”, European Commission Report.

Howell, A.J. (2016), "Firm R\&D, innovation and easing financial constraints in china: does corporate tax reform matter?”, Research Policy, Vol. 45 No. 10, pp. 1996-2007.

Jaffee, D. and Russell, T. (1976), "Imperfect information, uncertainty, and credit rationing", The Quarterly Journal of Economics, Vol. 90 No. 4, pp. 651-666.

Jensen, M.B., Johnson, B., Lorenz, E. and Lundvall, B.Å. (2007), "Forms of knowledge and modes of innovation", Research Policy, Vol. 36 No. 5, pp. 680-693.

King, R.G. and Levine, R. (1993), "Finance and growth: Schumpeter might be right", The Quarterly Journal of Economics, Vol. 108 No. 3, pp. 717-737.

Kon, Y. and Storey, D. (2003), "A theory of discouraged borrowers", Small Business Economics, Vol. 21 No. 1, pp. 37-49. 
Lee, N. and Brown, R. (2016), "Innovation, SMEs and the liability of distance: the demand and supply of bank funding in UK peripheral regions", Journal of Economic Geography, Vol. 17 No. 1, pp. 233-260.

Lee, N., Sameen, H. and Cowling, M. (2015), "Access to finance for innovative EMEs since the financial crisis”, Research Policy, Vol. 44 No. 2, pp. 370-380.

Levenson, A. and Willard, K. (2000), "Do firms get the financing they want? Measuring credit rationing experienced by small businesses in the US”, Small Business Economics, Vol. 14 No. 2, pp. 83-94.

McFadden, D. (2001), “Economic choices”, American Economic Review, Vol. 91 No. 3, pp. 351-378.

March, J.G. (1991), "Exploration and exploitation in organizational learning", Organization Science, Vol. 2 No. 1, pp. 71-87.

Mazzucato, M. (2013), "Financing innovation: creative destruction vs. destructive creation", Industrial and Corporate Change, Vol. 22 No. 4, pp. 851-867.

Mazzucato, M. and Semieniuk, G. (2018), "Financing renewable energy: who is financing what and why it matters", Technological Forecasting and Social Change, Vol. 127, pp. 8-22.

Mina, A., Lahr, H. and Hughes, A. (2013), "The demand and supply of external finance for innovative firms", Industrial and Corporate Change, Vol. 22 No. 4, pp. 869-901.

Mohnen, P., Palm, F.C., Van Der Loeff, S.S. and Tiwari, A. (2008), "Financial constraints and other obstacles: are they a threat to innovation activity?", De Economist, Vol. 156 No. 2, pp. 201-214.

Murray, G. (1999), "Seed capital funds and the effect of scale economies", Venture Capital: An International Journal of Entrepreneurial Finance, Vol. 1 No. 4, pp. 351-384.

Musso, P. and Schiavo, S. (2008), "The impact of financial constraints on firm survival and growth", Journal of Evolutionary Economics, Vol. 18 No. 2, pp. 135-149.

Myers, S.C. and Majluf, N.S. (1984), "Corporate financing and investment decisions when firms have information that investors do not have", Journal of Financial Economics, Vol. 13 No. 2, pp. 187-221.

Nightingale, P. and Coad, A. (2014), "Muppets and gazelles: political and methodological biases in entrepreneurship research", Industrial and Corporate Change, Vol. 23 No. 1, pp. 113-143.

Ning, Y., Wang, W. and Yu, B. (2015), "The driving forces of venture capital investments", Small Business Economics, Vol. 44 No. 2, pp. 315-344.

Paunov, C. (2012), “The global crisis and firms' investments in innovation”, Research Policy, Vol. 41 No. 1, pp. 24-35.

Pellegrino, G. and Savona, M. (2017), "No money, no honey? Financial versus knowledge and demand constraints on innovation”, Research Policy, Vol. 46 No. 2, pp. 510-521, paper for 35th DRUID conference, Barcelona, June 17-19.

Savignac, F. (2008), "Impact of financial constraints on innovation: what can be learned from a direct measure?", Economics of Innovation and New Technology, Vol. 17 No. 6, pp. 553-569.

Silva, F. and Carreira, C. (2012), "Do financial constraints threat the innovation process? Evidence from Portuguese firms", Economics of Innovation and New Technology, Vol. 21 No. 8, pp. 701-736.

Simon, H.A. (1955), "A behavioral model of rational choice", The Quarterly Journal of Economics, Vol. 69 No. 1, pp. 99-118.

Stiglitz, J. and Weiss, A. (1981), "Credit rationing in markets with incomplete information", American Economic Review, Vol. 71 No. 3, pp. 393-410.

Stinchcombe, A.L. and March, J.G. (1965), "Social structure and organizations", Handbook of Organizations, Vol. 7, pp. 142-193.

Tylecote, A. (2007), "The role of finance and corporate governance in national systems of innovation", Organization Studies, Vol. 28 No. 10, pp. 1461-1481.

Uzzi, B. (1999), "Embeddedness in the making of financial capital: how social relations and networks benefit firms seeking financing”, American Sociological Review, Vol. 64 No. 4, pp. 481-505. 
Uzzi, B. and Lancaster, R. (2003), "Relational embeddedness and learning: the case of bank loan managers and their clients", Management Science, Vol. 49 No. 4, pp. 383-399.

Van de Ven, W.P. and Van Praag, B. (1981), "The demand for deductibles in private health insurance: a probit model with sample selection", Journal of Econometrics, Vol. 17 No. 2, pp. 229-252.

Radical and incremental innovation

Vermoesen, V., Deloof, M. and Laveren, E. (2009), "Long-term debt maturity and financing constraints of SMEs during the global financial crisis”, Small Business Economics, pp. 1-16.

Westhead, P. and Storey, D. (1997), "Financial constraints on the growth of high technology small firms in the United Kingdom", Applied Financial Economics, Vol. 7 No. 2, pp. 197-201.

\section{Corresponding author}

Daniel Stefan Hain can be contacted at: dsh@business.aau.dk

For instructions on how to order reprints of this article, please visit our website: 